\title{
Study of Erosion Control Techniques Applied to Hydroelectric Power Plants Reservoir Margins
}

\author{
By Terezinha C. De Brito Galvão* \\ Arnaldo Teixeira Coelho ${ }^{\dagger}$ \\ Gustavo Borel de Menezes ${ }^{t}$ \\ Enio M. Brandão de Fonseca
}

This paper aims to provide relevant results of research performed on erosion control processes at water reservoir margins under tropical conditions. This large-scale streambank erosion control study is located on the margins of the water reservoir at Volta Grande Hydroelectric Power Plant in Brazil. This reservoir lake occupies an area of $220 \mathrm{~km} 2$, and is located in the border of the states of Minas Gerais and São Paulo. Three experimental sites, with fast bank retreat, were identified for the implementation of these erosion control works: Pier (2,700 m2), Baia (3,524 m2), and Miguelopolis (1,280 m2), in a total study area of 7,500 $\mathrm{m} 2$ and length of $500 \mathrm{~m}$, around the reservoir lake. Eleven different bioengineering treatment techniques, vegetated and armored techniques, were implemented on 27 parcels on these three study-areas, as follows: Straw logs and Coir logs (biologs); three metallic gabions coated with polymers and PVC- bags, box, and mattress; Polypropylene (PP) P550 geotextile; PP geotextile C350; Sintemax geotextile; MacMat geotextile; and wood crib wall. Laboratorial and field testings and measuremnents included geotechnical studies, fertility, turbidity, wind velocity, wave height, stratigraphy of the study area, and in situ permeability. All obtained geotechnical results pointed that the streambank soil is erosion prone. Collected data over a period of three years were summarized in a Performance Matrix. Turbitidy, wave height and wind velocity measurements were difficult to correlate, and could not provide much information on soil loss. Thus, to gather more data on the sediment acumulated in front of each treatment, differential bathymetry was performed and plotted by using ArcGIS map algebra. Under the studied conditions, the best biotechnical methods were armored techniques such as Gabion mattress associated with geotextile, and rip rap associated with Gabion mattress, whereas vegetated biologs and crib walls had the worst performance. Also, the use of vegetation soley was not an efficient method for controlling erosion.

Keywords: Biotechnical Method, Shoreline Protection, Streambank Erosion Control.

\section{Literature Review}

Soil erosion is a hazard in almost every country in the world. Traditionally, the focus of erosion control research has been on loss of topsoil in agricultural

\footnotetext{
*Professor, Spelman College, USA.

†Ingá Engenharia, Brazil.

†Professor, California State University, USA.

•Director, Centrais Elétricas de Minas Gerais, Brazil.
} 
areas and to some extent, linked environmental damages through sedimentation, pollution and increased flooding. Accelerated soil erosion rate, either natural or anthropogenic, results in the loss of fertile and increased sedimentation of waterways. FAO (2015) states that, most likely, the range of soil loss by water erosion is about 20-30 $\mathrm{Gt} \mathrm{yr}^{-1}$, corresponding to an estimated economical loss of 400 billion dollars $\mathrm{yr}^{-1}$. Thus, controlling erosion processes has become a very important subject and an object of a great number of studies. In the last decades, the focus of erosion studies became widespread. It incorporated besides the traditional agriculture concerns, such as the loss of fertile topsoil, also concerns related to the significant impairment of waterways due to sediment deposition. This current research also addresses the erosional processes that can take places on cohesive streambank soils at the margins of hydroelectric power plants water reservoirs. Despite the great amount of research on predicting erosion on cohesive streambank, the subject has remained a difficult topic. Three main processes have been identified in streambanks as responsible for the soil loss: subarearial erosion, fluvial entrainment or scour, and mass failure (Grove et al., 2013; Thorne, 1982). Subaerial erosion is often regarded as a preparatory process, in contact with air, aiming to lower the shear strength prior to fluvial erosion. It exclude processes during periods of inundation. Fluvial entrainment or scour, is the direct removal of sediment by the river hydrological processes. Physically, a rotational failure can often be identified in the field by the deep seated, curved failure scars; intact bank failure blocks back-tilted towards the scar; and arcuate shape of the intact bank line behind the failure mass (Thorne, 1993). The failed material may not be a coherent block(s), and may occur as a wet flow (Thorne, 1993). Researchers have been pointing out that fluvial entrainment and mass failures are often interlinked (Darby et al., 2007; Rinaldi and Darby, 2008; Rinald and Nardi, 2013) with the basal undercutting of a riverbank lowering the bank factor of safety (FS), so that riverbanks with an excess basal capacity (Osman and Thorne, 1988) are likely to become unstable. Mass failures would be expected to occur in areas of high banks and leave signature failure scars and blocks that can be interpreted to infer process(es). Some other researchers incorporate a fourth category named cantilever failure. Cantilever failures may also occur in more cohesive or massive sediments due to pop-out failures. The basal removal of sediment by seepage can cause failures in the lower bank, leaving a characteristic alcove-shaped indentation and failed blocks pushed out, or down slope, of the indentation (Dapporto et al., 2003). The upper bank is left unsupported and vulnerable to cantilever failure.

\section{Biotechnical Methods}

Plants, logs, and rocks have been used in the Roman Empire, China and many other countries over the past centuries to stabilize rivers. However, in the last 50 years, those traditional uses of plants have been re-discovered, and at light of new technology and a more environmental awareness they have been improved and are known as biotechnical methods.

In the USA, the study of biotechnical methods started during 1970's, due to the following factors - increased environmental awareness associated with the 
increased number of failures of some traditional engineering methods. One specific situation that almost always guarantees a failure is the use of hardarmoring (concrete) only around the bridge abutments and streambanks, upstream and downstream of a bridge ( $\mathrm{Li}, 2002)$.

The accepted definition of biotechnical methods is the use of live plants in association of inert materials such as timber, rocks, concrete, and geotextiles to control erosion or stabilize soil (slope).

Along the last 50 decades, the interest of engineers to introduce plants (biological and ecological concepts) aiming the preservation of native species and habitats increased with time.

Simultaneously, a great number of researches took place globally in the last decades to study the role of these new biotechnical construction methods, such as to determine better engineering construction procedure of using plants, the role of vegetation, in special, the riparian vegetation in soil erosion control and estabilization. Additionally, it became important to quantify the impact of plants on streambanks and on slope stability.

So far, published literature have outlined the following advantages for the use of biotechnical methods: (i) Technical advantages - protection against surface erosion, an increase of soil resistance by root reinforcement and draining of the soil, protection against rock fall and wind; (ii) Ecological advantages - regulation of temperature and humidity close to the surface, promoting plant growth, and improvement of soil water regime via increase of infiltration and recharge of aquifers, evapotranspiration, soil improvement, improvement of and provision for habitat; (iii) Economical advantages - reduction of construction and maintenance costs, creation of areas for agricultural and recreational use; (iv) Asthetic advantages - structures fit into the landscape, landscape is more appealing.

Nowdays, geotechnical and hydraulic engineering practice are using a wide range of biotechnical methods to estabilize slopes and to control top soil erosion.

Research results shows that the vegetation can influence the following hydrological and mechanical mechanisms on soil slope (Gray and Sotir, 1996; Schiechtl, 1980): (i) interception on foliage - reduces rainfall by adsorption and evaporation; (ii) infiltration capacity is increased due to higher ground surface roughness and permeability; (iii) transpiration of water-uptake by roots lower pore-water pressure; (iv) dessiction-cracking of soil due to transpiration - cracks increase water permeability; (v) anchoring of topsoil into firm strata - buttressing and arching; (vi) increase of surchage by vegetation weight - increase normal and downhill forces; (vii) dynamic forces (momentum) caused by wind led into the slope via vegetation; (viii) reduced erosion by dense root webs; (xix) soil reinforcement by roots increase shear strength

\section{Role of Vegetation on the Increase of Shear Strength}

The recognized main role vegetation in controlling erosional processes lies on the absorption of the kinetic energy from the rain splash, and prevent the subsequent detachment from the soil matrix. In the riparian zone, vegetation 
secures banks, regulates micro-clima of streams and offers terrestrial habit, and a food source for terrestrial and aquatic life.

From the geotechnical point of view roots and root architecture can reinforce soil, through its tensile resistance of the roots and as such has the potential to increase the shear resistance of the soil due to the added apparent cohesion given by roots (Gray and Sotir, 1996; Zhang et al., 2014). This apparent root cohesion is a product of the root cross-section area per unit area of soil and root tensile strength (Wu et al., 1979). Although the root architecture is function of the plant type and determined genetically, its growth can be influenced by: local soil conditions, altitude and latitude, water availability and plant nutrients, climatic factors, and seasonal changes, among others. The root architecture must be kept alive (throughout the life of the structure) and its roots must reach greater depths until to the most probable zone of rupture in the banks (or slopes).

The soil reinforcement provided by roots was derived from modified Coulomb's Law shear strength equation, as an added increment of shear strength, $\Delta \mathrm{S}$ (Waldron, 1977):

$S=c+\Delta S+\sigma_{N} \tan \varphi$
$\Delta S=T S(\sin \theta+\cos \theta \tan \varphi)\left(A_{r} / A\right)$

where $\Delta \mathrm{S}$ is the root additional shear resistance; $\varphi$ is the internal friction angle, $\sigma_{\mathrm{N}}$ is the normal pressure, $\mathrm{A}_{\mathrm{r}} / \mathrm{A}$ is the ratio of root cross-section area per unit area soil of the shear plane, TS is the tensile strength of the roots, and $\Theta$ is the angle of the shear plane.

Finer roots are stronger and provide more resistance than thicker roots (Ye et al., 2017). Vegetation through its fine root architecture provides additional soil resistance to erosional processes and entraps the soil into the soil matrix. A great number of researches has been produced on the use of vegetation to control erosional processes (Gray and Sotir, 1996; Zhang et al., 2014; Ye et al., 2017; Coelho, 2001b). However, depending on the site conditions, inert elements need to be added to the vegetation to provide more reinforcement. In summary, biotechnical methods are a combination of biological, mechanical, and ecological concepts to control erosion and stabilize soil through the use of vegetation or a combination of vegetation and construction materials (Coelho, 1999; Gray and Sotir, 1996).

It is important to mention that the choice of plants for biotechnical structures does not only depend on root strength characteristics but has to incorporate other factors such as: succession, propagation, growth quality, soil stabilization and anchoring qualities of the root system, physical and chemical soil characteristics, climatic aspects among others.

\section{Basic Biotechnical Construction}

Plants can be placed in association of other inert materials, such as geotextiles, rocks (rip-rap), concreted materials, gabions, logs (crib-walls), among others as function of the complexity of the problem to be solved, and the site conditions. 
The use of geotextile in association with plants is the most common basic biotechnical method. It is usually used to stabilize loose top soil layers until the rooting system is established. They are typically made of biodegradable materials such as jute, coconut fibers, or synthetic fibers. Also, long-term geotextiles could be used, made usually of UV-stabilized polypropylene or polyethylene, polyester or polyamids. Ultraviolet radiation protection is important for situations where the geotextile is place on the top soil. In general, the choice of the geotextile to be used is function of the area, the soil characteristics, type of vegetation, time of planting, duration for the development of the root-system, among others.

For streambanks, controlling and stabilizing erosion processes can become more complex, and may require the use of hard-armoring techniques such as gabions, stone riprap in association with plants and geotextiles. Also, it involves not basic principles of geotechnical and hydraulic engineering but also fluvial engineering, geomorphology, ecology, botany, and landscape.

The main contribution of all components of the biotechnical construction are basically the following: (i) the increase of soil resistance by the increase of tensile resistance of the root mass; (ii) increase of soil shear strength by reducing porepressures through transpiration; and/or (iii) anchoring the slope through deep root penetration into more stable strata (Gray and Sotir, 1996; Riley, 1998; Allen and Leech, 1997).

Three authors have been widely recognized for their foundational work on biotechnical stabilization research and practice: (i) Schiechtl, 1980 - (266 citations) \& Schiechtl and Stern, 1996 (122 citations); (ii) Gray and Sotir, 1996 (896 citations), Gray and Leiser, 1982 (646 citations); (iii) Coppin and Richards, 1990 (566 citations); Greenway, 1987 (620 citations). Also, the role of the Department of Agriculture (2016) and Corps of Engineers (1998) has been recognized. Almost all the literature produced in the USA after 1980 has been based on the foundation built by Schiechtl in 1980 .

In summary, even though biotechnical techniques for erosion control have been around for centuries, it was only in the last decade that it became widely used due to its intrinsic advantages: low implementation cost, low greenhouse gases footprint, preservation of local biodiversity and habitats, and better landscape aesthetics, among others (Gray and Sotir, 1996; McCullah and Gray, 2005; Morgan, 1994; Coelho, 1999; NRCS, 2012; Coppin and Richards, 1990).

In this study, a wide range of biotechnical methods are proposed to control streambank erosion by providing resistance against the impact of waves from the water reservoir, and by protecting the bank against fluvial, mass and cantilever failures. It aims to provide relevant information on the erosional processes at reservoir margins, which are very significant in Brazil, where the perimeter of all Brazilian water reservoirs for hydroeletric power plants is about the same as the Brazilian coast perimeter $-6,000 \mathrm{~km}$. 


\section{Methodology}

\section{Site Description}

Three study areas named Pier, Baia and Miguelopolis covering 7,500 $\mathrm{m}^{2}$ were selected on the margins of the water reservoir lake at the Volta Grande hydroelectric power plant, which is located at the borders of Minas Gerais and São Paulo states, Brazil, and ocuppies an area of $220 \mathrm{~km}^{2}$. The three study areas were selected based on the following criteria: (i) the streambank was actively retreating through a combination of fluvial erosion, mass and cantilever failure; and (ii) the streambank soil profile and geomorphology were similar to those observed at other sites along the water reservoir.

On these three study areas, 28 parcels of bioengineering techniques were implemented and monitored for three years.

Climate of the study areas is classified as Cwa according to Koppen, that means tropical savannah, moist and hot, with a dry season from April to September, and $80 \%$ of rainy pseason lasts from October to March. The mean annual temperature is $23.5^{\circ} \mathrm{C}$, with minimum temperature around $16.5^{\circ} \mathrm{C}$ and maximum temperature around $29.2^{\circ} \mathrm{C}$. The annual precipitation for the study area is around 1,400 $\mathrm{mm}$. The streambank soil profile is characterized by homogeneous red latosol according to Embrapa (2011) and Oxisol according to US Soil Taxonomy (USDA, 1975).

The native vegetation of the area is mainly composed of Caryocar brasiliense (pequi), Aspidosperma tomentosum (perobeira do campo), Stryphnodendron adstringens (barbatimão), Copaifera langsdorffii (copaíba do cabloco), and Tabebuia ochracea (ipê do cerrado). Starting in the 1940s, native vegetation has been replaced with planted pastures of Brachiaria decumbens and Hyparrenia rufa. In the 1990s, Pennisetum purpureum was planted in the area in an attempt to stabilize and mitigate the erosive effect of waves on the reservoir streambanks. However, the approach was not successful, as the banks kept retreating at a rate of about $1 \mathrm{~m} /$ year.

\section{Biotechnical Techniques}

Vegetation in combination with a wide range of inert elements (bioengineering techniques) was implemented in the study areas. It includes rolled erosion products (RECPs) made of synthetic (geotextile) or natural materials (straw or coconut fiber) were implemented either by itself, or combined with armored engineering erosion control techniques (gabion, and crib wall) in the three study areas. They were: (i) rolled erosion product - C350 - produced by North American Green (NAG), USA; (ii) rolled erosion product -P550 - NAG/USA; (iii) crib wall; (iv) rip rap; (v) rip rap + vegetated bag Gabion; (vi) vegetated biologs filled with straw; (vii) vegetated biologs (filled with straw) + Sintemax geotextile from Deflor Bioengineering/Brazil; (viii) vegetated MCMat (Maccaferri/Brazil) + bag Gabion; (xix) vegetated biologs filled with coconut fiber (coir logs); (xx) vegetated biologs 
with coconut fiber + Sintemax; (xxi) vegetated Gabion $(4 \mathrm{~m})$; (xxii) vegetated mattress Gabion (5m); (xiii) Sintemax and MacMat.

For the treatments, a seed cocktail was used that has shown successful growth under tropical conditions as well as a great trampling (walk over) resistance (Coelho and de Brito Galvão, 1998; Coelho et al., 2001a; Coelho et al., 2001b). It included the species: Brachiaria humidicola, Pannisetum purpureum, Panicum maximum, Camipim, Mimosa sp., Cajanus cajan, Melia azedarach, Clitoria racemosa, Schinus mole, Enterolobium contorstisilquim, and Anadenanthara sp.

Testings

Laboratorial and field testings and measurements included a wide range of geotechnical studies (Atterberg Limits, granulometry, density, in situ permeability Guelph, shear strength with soil and soil/roots soil survey), soil fertility, and laboratory turbidity measurements of water samples collected in front of each treatment, measurements of wind velocity, and wave height. These last three were done twice a month for three years.

\section{Results/Discussion}

The below findings are focused only on the Pier study area, which encompasses 11 treatment parcels, occupying an area of $2,700 \mathrm{~m}^{2}$ and length of $212 \mathrm{~m}$.

Based on results from Atterberg Limits, soil granulometry, and in situ Guelph permeability testings, soils were classified as erosion prone (sandy-clayey silt, non plastic, with permeability in the range of $10^{-4} \mathrm{~cm} / \mathrm{s}$ ). Except for potassium values, which presented low values, all remaining soil macronutrients $(\mathrm{P}, \mathrm{Ca}, \mathrm{Mg}, \mathrm{Al}$, $\mathrm{H}+\mathrm{Al}$, organic matter) were in the normal range (EMBRAPA, 2011). The soil $\mathrm{pH}$ was 6.6, slightly acid. Soil erodibility measured according to Wishchmeir and Smith (1978) was about 0.41 .

Figures 1 to 3 depict the implementation of the selected bioengineering treatments, and at after the vegetation growth.

Figure 1. a) Coconut Fiber Biologs Covered by RECP from Deflor, at Pier, in 2002 and b) Same Area with Consolidated Vegetation, at Pier, in 2007

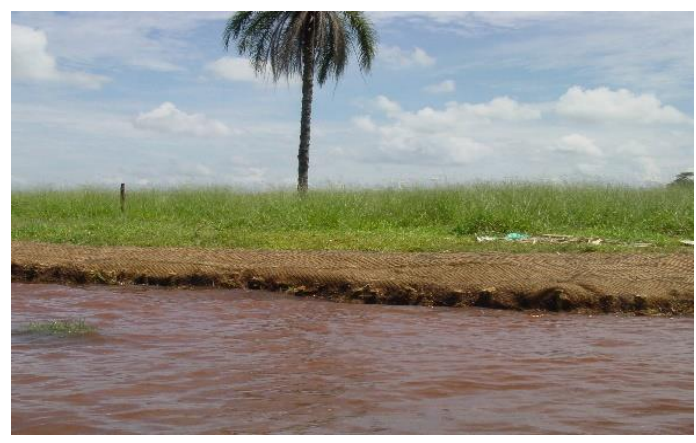

a)

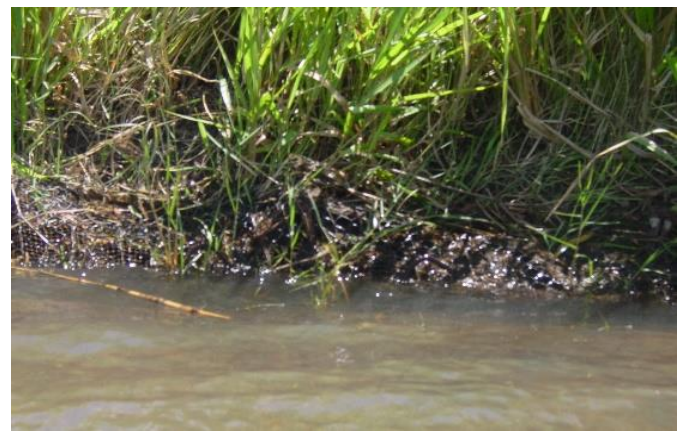

b) 
Figure 2. a) C350 from NAG/USA in 2002 and b) C350 from NAG/USA at Beginning of Consolidating the Vegetation

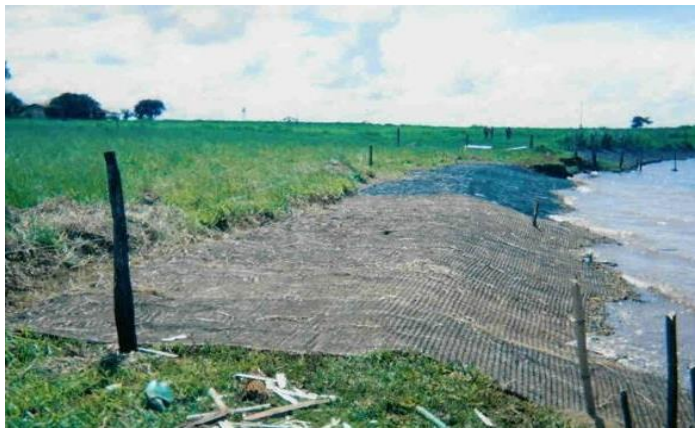

a)

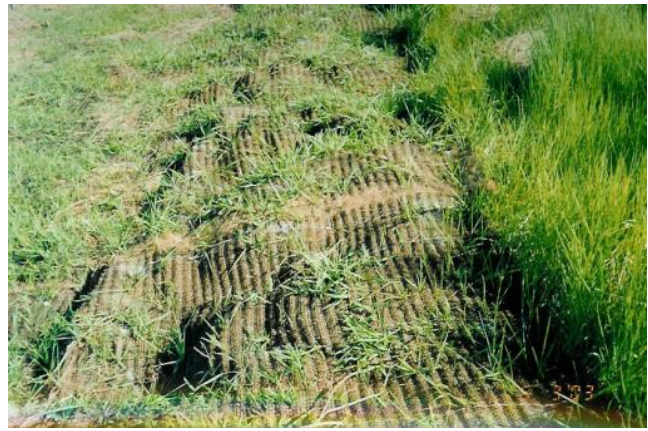

b)

Figure 3. a) Implementation of Gabion Mattress in 2002 and b) Gabion Mattress at Beginning of Vegetation Consolidation in 2004

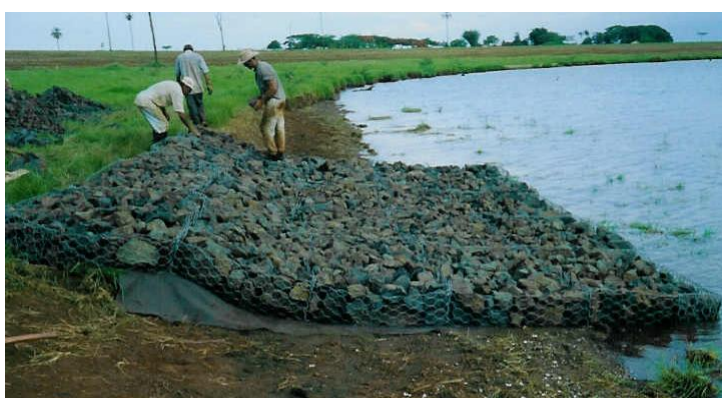

a)

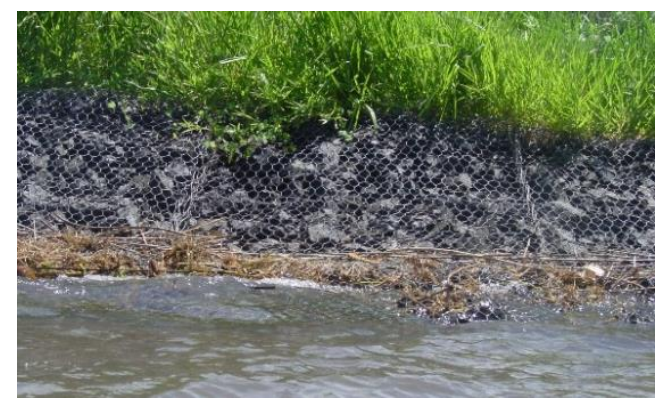

b)

Data collected on wind velocity, turbidity and wave height did not seem to provide much information on sediment accumulation in front of each treatment. In this sense, a performance matrix was created to gather all field observations made throughout 3 years.

Table 1 presents the performance matrix in where each treatment was rated using the following criteria: streambank integrity against erosion; vegetative cover growth, costs, structural integrity, need for maintenance, aesthetics and landscape integration, and regrowth of native vegetation. 
Table 1. Performance Matrix of All Treatments Located on Pier Study Area (2700 $m^{2}$ )

\begin{tabular}{|c|c|c|c|c|c|c|c|c|c|c|c|}
\hline Variable & Weight & \multicolumn{10}{|c|}{ Value } \\
\hline Treatment & & P1 & P2 & P3 & P4 & P5 & & P8 & P9 & P10 & P11 \\
\hline 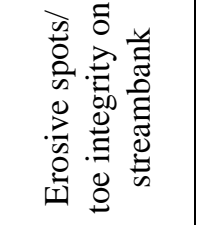 & $\begin{array}{c}\text { High }-0 \\
\text { Intermediate }-1 \\
\text { Low }-2 \\
\text { Inexistent }-3\end{array}$ & 0 & 1 & 3 & 2 & 3 & 3 & 2 & 2 & 2 & 2 \\
\hline 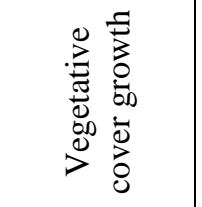 & $\begin{array}{l}\text { Bare }(<30 \%)-0 \\
\text { Low vegetative cover }(30 \text { to } \leq 50 \%)-1 \\
\text { Average vegetative cover }(>50-\leq 70 \%)-2 \\
\text { High vegetative cover }(>70-100 \%)- \\
3\end{array}$ & 0 & 3 & 3 & 3 & 3 & 3 & 3 & 3 & 3 & 3 \\
\hline 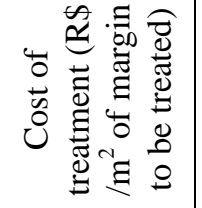 & $\begin{array}{l}\text { Very High }(>300)-0 \\
\text { High }(150-300)-1 \\
\text { Average }(50-150)-2 \\
\text { Low }(<50)-3\end{array}$ & 2 & 3 & 2 & 1 & 0 & 0 & 2 & 2 & 2 & 1 \\
\hline 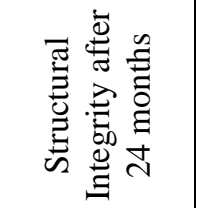 & $\begin{array}{c}\text { Serious damage }(>30 \% \text { of the total })-0 \\
\text { Average damages }(10-30 \% \text { of the total })-1 \\
\text { Low level of damage }(<10 \% \text { of the total })- \\
2 \\
\text { No damage }-3\end{array}$ & 0 & 1 & 3 & 1 & 3 & 3 & 2 & 2 & 2 & 1 \\
\hline 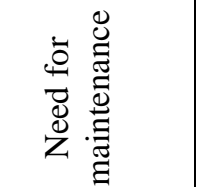 & $\begin{array}{c}\text { High }(>\text { de } 5 \text { times })-0 \\
\text { Average }(3 \text { to } 5 \text { times })-1 \\
\text { Low }(1-2 \text { times })-2 \\
\text { No need }-3\end{array}$ & 0 & 1 & 2 & 3 & 3 & 3 & 0 & 0 & 1 & 0 \\
\hline 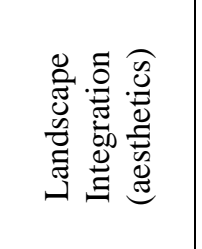 & $\begin{array}{c}\text { No integration with local landscape }-0 \\
\text { Integration with local landscape after } 12 \\
\text { months - } 1 \\
\text { Integration with local landscape after } 6 \\
\text { months - } 2 \\
\text { Integration since the startup -3 }\end{array}$ & 0 & 2 & 2 & 1 & 1 & 1 & 2 & 2 & 2 & 1 \\
\hline 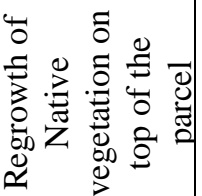 & $\begin{array}{c}\text { Absence of native flora }-0 \\
\text { Presence of 1-3 native species }-1 \\
\text { Presence of 3-5 species }-2 \\
\text { Presence of more than } 5 \text { native species }-3\end{array}$ & 1 & 1 & 2 & 3 & 3 & 3 & 1 & 1 & 1 & 0 \\
\hline & TOTAL & 3 & 12 & 17 & 14 & 16 & 16 & & 12 & 13 & 8 \\
\hline
\end{tabular}

Legend: P1 - vegetated biologs (filled with straw) + Sintemax geotextile from Deflor Bioengineering/Brazil; P2 - rip-rap; P3- rip-rip + bag Gabion; P4- MacMat geotextile from Maccaferri/Brazil + bag Gabion; P5- rip-rap + Gabion mattress; P6 - Gabion mattress + MacMat geotextile from Maccaferri/Brasil; P7 - rip rap; P8- geotextil P550 from North American Green/USA; P9 - geotextil C350 from North American Green/USA. 
According to Table 1, the treatments that performed the best were as follows: P3 followed by P5, P6, P4 and P10.

Although this table can give information on the overall performance of each treatment, it does say very little about sediment deposition in front of each parcel. Also, turbidity data varied so much that it became difficult to see any trend as function of wind velocity/direction, wave height, and specific treatment.

It was decided then to use differential bathymetry (final bathymetry - initial bathymetry) developed using in ArcGIS map algebra, to identify soil loss/accumulation in front of each treatment.

Figure 4 shows the differential bathymetry ploted using ArcGIS.

Figure 4. Differential Bathymetry Plotted using ArcGis, in where P1 - Vegetated Biologs (Filled with Straw) + Sintemax Geotextile from Deflor Bioengineering/ Brazil; P2 - rip-rap; P3- rip-rip + bag Gabion; P4- MacMat Geotextile from Maccaferri/Brazil + bag Gabion; P5- rip-rap + Gabion Mattress; P6 - Gabion Mattress + MacMat Geotextile from Maccaferri/Brasil; P7 - rip rap; P8Geotextile P550 from North American Green/USA; P9 - Geotextile C350 from North American Green/USA

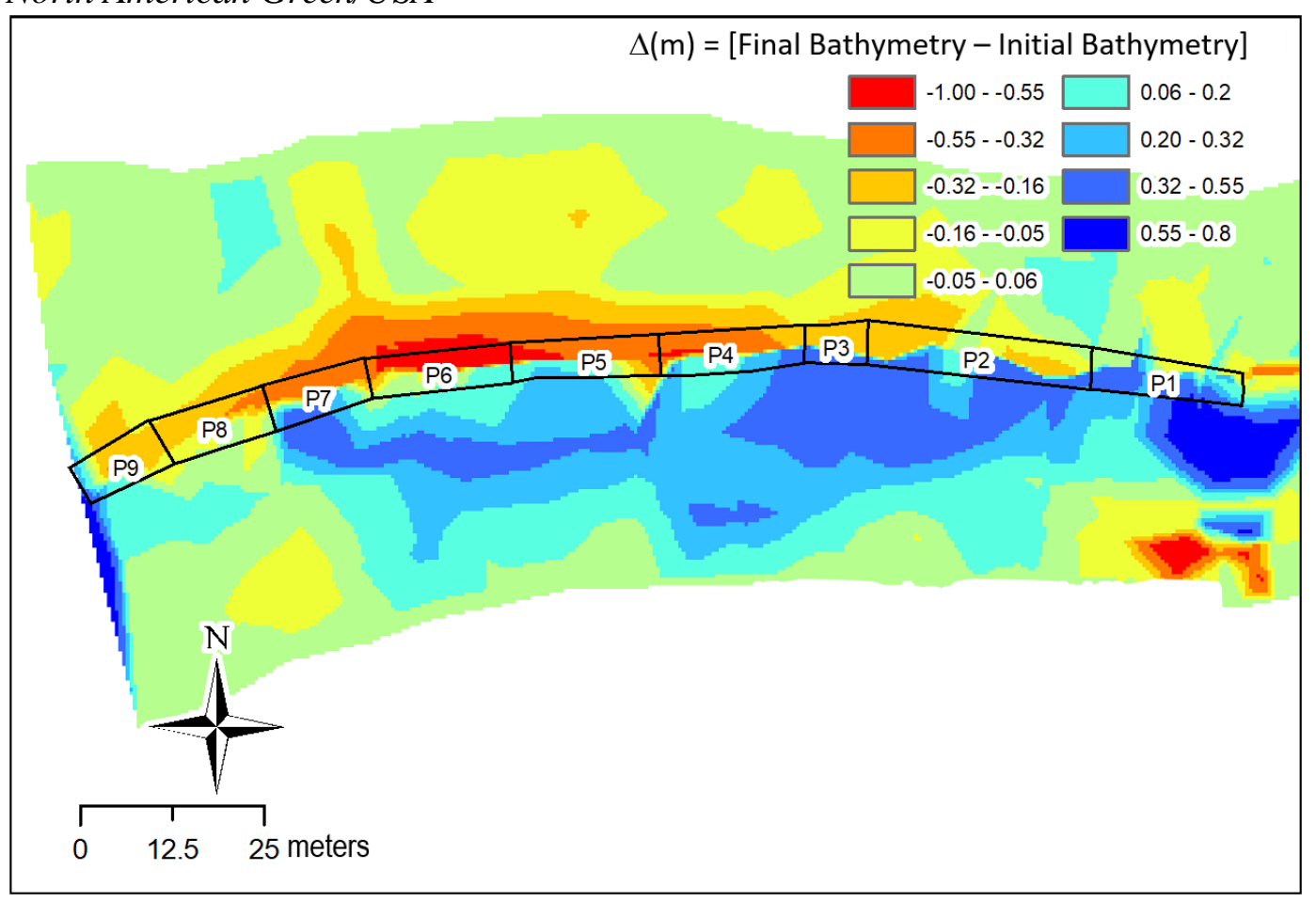

According to this differential bathymetry the treatments with less soil deposition in front of them were as follows: P6, P8, P9, and P5.

Table 2 shows the summary of the best treatment performance according to differential bathymetry and matrix of performance. 
Table 2. Comparison of Treatments using Matrix Performance and Differential Bathymetry

\begin{tabular}{|l|l|}
\hline & Treatments \\
\hline Performance Matrix & P3 followed by P5, P6, P4 and P10 \\
\hline Differential Bathymetry & P6, P8, P9, and P5 \\
\hline
\end{tabular}

By superimposing these results, we can conclude that for the studied site conditions, treatements P6 and P5 performed the best - both are armored techniques (P6 -Gabion mattress associated with geotextile, and P5 - rip rap with Gabion mattress). In conclusion, it is important to have armored techniques associated with vegetation to control streambank erosion.

\section{Conclusions}

Results presented here for the study area, indicated that it was not possible to differentiate among the following types of bank erosion - aerial, fluvial, mass failure and cantilever failure, and how much each one contributed to the overall bank retreat process. However, from pictures, it was clear that a cantilever beam was formed, and the toe was totally eroded, before the slope came down in slip failure. Soil fertility studies show that the studied soils have low fertility for $\mathrm{K}$ and that all other essential macro nutrients $(\mathrm{P}, \mathrm{Ca}, \mathrm{Mg}, \mathrm{Al}, \mathrm{H}+\mathrm{Al}$, organic matter) responsible for plant growth were in normal range. Soil $\mathrm{pH}$ was 6.6, slightly acid. Geotechnical testing indicated by Atterberg Limits results showed that the studied soils are non-plastic. The granulometric size distribution results classified the soil as sandy-clayey silt, and as such the in-situ soil is erosion prone. Also, the Guelph field permeability results indicated that the studied soils have permeability around $10^{-4} \mathrm{~cm} / \mathrm{s}$. This value for permeability falls in the range of a silt soil, which also indicates that the soil is erosion prone. Soil erodibility measured according to Wishchmeir and Smith (1978) was about 0.41 (average erodibility). Maximum values that soil erodibility can reach in RUSLE equation is 1 . Geotechnical testing in association with permeability and erodibility testing points out that the soils in the study area are geologically erosion prone and the implementation of erosion control techniques are needed to stop the advancement of erosion processes from the impact of waves in the lake reservoir. In situ, turbidity results could not be analyzed as absolute values, as they couldn't distinguish between the turbidity generated by waves impact with the upstream turbidity. In conclusion, from all implemented treatments the numbers P6 and P5 performed the best - both are armored techniques (P6 -Gabion mattress associated with geotextile, and P5 - rip rap with Gabion mattress), whereas vegetated biologs (independent of the filled materials used) and crib walls had the worst performance. 


\section{Acknowledgments}

The authors of this paper acknowledge and are thankful for the funding of this Project by Research \& Development Program of the National Agency of Electric Energy (ANEEL - Agência Nacional de Energia Elétrica) with support of "Companhia Energetic of Minas Gerais - CEMIG GT (CEMIG Geração e Transmissão)", Brazil.

\section{References}

Allen, H. H. and Leech, J. R. 1997. Bioengineering for Streambank Erosion Control, Environmental Impact Research Program Technical Report EL-97-8. US Army Corps of Engineers Waterways Experiment Station.

Coelho, Arnaldo T. 1999. Avaliação dos efeitos do recobrimento vegetativo nos processos erosivos laminares em talude de corte rodoviário, em Ribeirão das Neves/MG [Evaluation of the effects of vegetative cover on the laminar erosive processes in road cut slope, Ribeirão das Neves / MG]. Master Degree Dissertation. Engineering School. Belo Horizonte, Brazil.

Coelho, A. T. and de Brito Galvão, T. C. 1998. Controle de Erosão em Taludes de Disposição de Rejeitos Siderúrgicos com Tapete Biodegradável [Control of Erosion in Slopes of Disposition of Steel Rejects with Biodegradable Carpet]. In: VI Simpósio Nacional de Controle de Erosão. Presidente Prudente, SP.

Coelho, A. T., de Brito Galvão, T. C. Pereira, A. R. 2001a. Evaluation of Two Biodegradable Rolled Erosion Control Products (RECP's) for Stabilizing Steep Slopes Under Tropical Conditions. In: $32^{\text {nd }}$ Annual International Erosion Control Association Expo - International Erosion Control Association, 2001, Las Vegas. Proceedings of the International Erosion Control Association. Las Vegas.

Coelho, A. T., de Brito Galvão, T. C., Pereira, A. R. 2001b. The effects of vegetative cover in the erosion prevention of a road slope. Environmental Management and Health; v. 12, n. 1.

Coppin, N. J. and Richards, I. G. 1990.Use of vegetation in civil engineering. Sevenoaks, Kent: Butterworts.

Dapporto, S., Rinaldi, M., Casagli, N. and Vannocci, P. 2003. Mechanism of river failure along the Arno River, central Italy. Earth Surface Processes and Landforms. 28(12): 233-245.

Darby, S. E., Rinaldi, M. and Dapporto, S. 2007. Coupled simulations of fluvial erosion and mass wasting for cohesive river banks. Journal of Geophysical Research 112(F3): F03022, http://dx.doi.org/10.1029/2006JF000722.

EMBRAPA - Empresa Brasileira de Pesquisa Agropecuária. 2011. Mapa de Solos do Brasil.

Food and Agriculture Organization (FAO). 2015 - http://www.fao.org/3/a-bc595e.pdf. [Acessed on April 25, 2018].

Gray, D. H. and Leiser, A, T. 1982. Biotechnical Slope Protection and Erosion Control. Nostrand Reinhold, New York.

Gray, D. H. and Sotir, R. B. 1996. Biotechnical and soil bioengineering slope stabilization - A practical guide for erosion control. New York: John Wiley \& Sons.

Greenway, D. R. Vegetation and Slope Stability. 1987. In: M.G. Anderson, K. S. Richards (Eds.). Slope Stability Geotechnical Engineering and Geomorphology, 187-230. Wiley. New York 
Grove, J. R., Croke, J., Thompson, C. 2013. Quantifying different riverbank erosion processes during an extreme event. Earth Surface Processes and Landforms 38, 1393-1406,

Li, Ming-Han and Eddleman, K. 2002. Biotechnical engineering as an alternative to traditional engineering methods - A biotechnical streambank stabilization design approach. Landscape and Urban Planning 60, 225-242.

McCullah, J. and D. Gray. 2005. National Cooperative Highway Research Program NCHRP Report 544 and Project 24-19. Transportation Research Board, Washington, DC.

Morgan, J. 1994. Soil erosion and conservation. U.K.: Silsoe.

NRCS - Natural Resources Conservation Service. 2012. Practice Standard Streambank and Shoreline Protection (Ft.) Code 580. https://bit.ly/2ze3FSw.

Osman, A. M. and Thorne, C. R. 1988. Riverbank Stability Analysis. I: Theory. Journal of Hydraulic Engineering, vol. 114, issue 2.

Riley, A. L. 1998. Restoring Streams and Cities. Island Press. Washington, DC.

Rinaldi M. and Darby, S. E. 2008. Modelling river-bank-erosion processes and mass failure mechanisms: progress towards fully coupled simulations. In: Gravel-Bed Rivers 6 - From Process Understanding to River Restoration, Habersack, H., Piegay, H., Rinaldi, M. (eds). Series Developments in Earth Surface Processes, Vol. 11, Elsevier: Amsterdam; 213-239.

Rinaldi, M. and Nardi, L. 2013. Modeling interactions between riverbank hydrology and mass failures. Journal of Hydraulic Engineering ASCE 18(10): 1231-1240.

Schiechtl, H. M. 1980. Bioengineering for Land Reclamation and Conservation. University of Alberta Press. Edmond. Canada.

Thorne, C. 1982. Processes and mechanisms of river bank-erosion. In: Gravel-Bed Rivers, Wiley, Chichester. UK, p. 227-259.

Thorne, C. R. 1993. Guidelines for the use of Stream Reconnaissance Record Sheets in the field. Contract Report HL-93-2. US Army Corps of Engineers: Washington, DC.

United States. Department of Agriculture. Soil Conservation Service - USDA. 1975. Soil taxonomy: a basic system of soil classification for making and interpreting soil surveys (No. 436). US Department of Agriculture.

United States Army Corps of Engineers (USACE). 1998. Shoreline and Channel Erosion Protection: Overview of Alternatives. WRP Technical Note HS-RS-4.1. Wetlands Research \& Technology Center, Environmental Laboratory, U.S. Army Engineer Research and Development Center, Wetlands Research Program, Vicksburg.

United States Department of Agriculture (USDA). 2016. In Engineering Field Handbook Part 650 Engineering Field Handbook National Engineering Handbook, Part 650, 210-EFH.

Waldron, L., 1977. The shear resistance of root-permeated homogeneous and stratified soil. Soil Science Society of America Journal, 41 (5), 843-849.

Wischmeier, W. H. and Smith, D. D. 1978. Predicting rainfall erosion losses: a guide to conservation planning. USDA Agricultural Handbook n. 537, Washington, DC.

Wu, T. H., McKinnell III, W. P. Swanston, D. N. 1979. Strength of tree roots and landslides on Prince of Wales Island. Canadian Geotechnical Journal 16(1), 19-33.

Ye, C., Zhonglu, G., Zhaoxia, L., Chongfa, C. 2017. The effects of Bahia grass on soil erosion resistance of Aquults in Subtropical China. Geomorphology 285, 82-93.

Zhang, C.-B., Chen, L.-H., Jiang. J. 2014. Why fine tree roots are stronger than thicker roots: The role of cellulose and lignin in relation to slope stability. Geomorphology. Vol. 206, 196-202. 
